\title{
Effect of Lopping Interval on the Growth and Fodder Yield of Subabul (Leucaena leucocephala)
}

\author{
C. Vennila ${ }^{1 *}$, M. Daisy ${ }^{2}$ and J. Bhuvaneswari ${ }^{3}$ \\ ${ }^{1}$ Department of Agronomy, TANVAS, Chennai, India \\ ${ }^{2}$ ICAR-Krishi Vigyan Kendra, VC \& RI campus, Namakkal, India \\ ${ }^{3}$ Department of Agronomy, AC and RI, Killikulam, India \\ *Corresponding author
}

\begin{tabular}{l} 
Key w o r d s \\
$\begin{array}{l}\text { Subabul, Tree } \\
\text { fodder, Lopping } \\
\text { interval, Yield } \\
\text { attributes, Fodder } \\
\text { yield }\end{array}$ \\
\hline Article Info \\
\hline $\begin{array}{l}\text { Accepted: } \\
\text { 26 August } 2020 \\
\text { Available Online: } \\
\text { 10 September } 2020\end{array}$ \\
\hline
\end{tabular}

\section{A B S T R A C T}

Subabul is an important protein rich tree fodder which its lopping is extensively used as cattle fodder. It is drought resistant tree, generally grown as border or bund crop in farmers and its lopping is cut for green fodder for animals. For this purpose tree fodder cultivating seems to be a promising strategy for livestock farmers. A field experiment was conducted to find out the relative performance of tree fodder growth at various stages of cutting and suitable lopping interval of subabul (Leucaena leucocephala) during 2019-2020, at Institute of Animal Nutrition, Kattupakkam, TANUVAS, Chennai. The experiment was conducted on sandy loam soil laid out with Randomized Block Design with three replications. There were six treatments viz., $\mathrm{T}_{1}$ : lopping once in 2 months, $\mathrm{T}_{2}$ : lopping once in 4 months, $\mathrm{T}_{3}$ : lopping once in 6 months, $\mathrm{T}_{4}$ : lopping once in 8 months, $\mathrm{T}_{5}$ : lopping once in 10 months and $\mathrm{T}_{6}$ : lopping in 12 months. The results showed that lopping at shorter time interval that is once in 2 months or 4 months resulted in more number of branches (10.90 and 7.84), leaves (427.6 and 461.3), leaf weight, leaf branch ratio (1.42 and 1.09) and increased fodder yield $\left(19.07 \mathrm{t}^{-1} \mathrm{ha}^{-1}\right.$ year $^{-1}$ and $17.72 \mathrm{t}^{-1} \mathrm{ha}^{-1}$ year $\left.^{-1}\right)$. Further, early lopping resulted in succulent leaves and branches which were highly suitable for the animals to consume.

\section{Introduction}

In the tropics most of the arable land is being utilized for high value food crops and industrial crop production (Chen et al., 1991). The ruminant livestock production in these areas plays a complementary role in utilizing the byproducts of crops and getting some income from land unsuited to crop production. The fibrous crop by products are the major potential feed resources and are obtained mostly from rice, cassava, maize, sorghum, sugarcane etc. The intake and digestibility of these feeds are not sufficient to sustain satisfactory levels of production. Supplementation with protein and also with 
soluble carbohydrates is very important for obtaining good production. The leaves from leguminous trees and shrubs are cheap and readily available sources of protein. One of the possible tree species used for feeding ruminants is subabul.

Subabul (Leucaena leucocephala) is a multipurpose sustainable leguminous tree in the tropics. It is named as wild tamarind is a low scrubby tree of tropical and subtropical area having white flowers tinged with yellow and long flattened pods. It is a thornless shrubby tree often only to $6-8 \mathrm{ft}$ but occasionally to 30-60ft. It grows very well in arid tropical climates and can become a best species in such climates. Grows best under full sun, needs little water or care once established. It grows well in all type of soil and as it tolerates low soil fertility, the crop yields can be boosted significantly by way of nitrogen fixation.. The tree has a huge wealth of uses, and is an extremely fast-grower, but care should be taken in some regions to control growth as the seeds are easily dispersed by birds and grazing cattle and the tree has the potential to become a pest. Leucaena leucocephala is used as green manure crop and fodder tree crop, it is well suited in agroforestry models. As a fodder purpose, Leucaena leucocephala is used as cut and carry forage for cattle, sheep and goats. Its high protein content allows it to complement low quality forages. For fodder purpose, repeated cutting is essential and this tree retains its leaves during dry season also. In most of the tropical conditions, this crop is primarily found as a fence crop around agricultural fields and lopping minimizes shading by trees which would be detrimental for better agricultural production. However, lopping only yields intermediate resource returns from trees (Rawat, 1993). In general, trees are lopped twice a year. Agroforestry systems based on tree species is important and the trees role in meeting present and future requirements of fuel wood, food, fodder, small timber and environmental protection is well recognized (Nair, 1987). The main lopping season coincides with the monsoon season. As most of the tree crops in agroforestry system are lopped extensively, scientific information is lacking. Hence, the present study is proposed to know the time of lopping in Leucaena leucocephala for fodder purpose.

\section{Materials and Methods}

A field experiment was conducted on sandy loam soil at Institute of Animal Nutrition, Kattupakkam during 2019-2020 to study the lopping interval and relative performance of tree fodder growth of subabul (Leucaena leucocephala) for animal fodder. The soil of the experimental site was sandy clay loam, well drained and having a $\mathrm{pH}$ of 7.6 and the available nitrogen, phosphorus and potassium were $232.0 \mathrm{~kg} \mathrm{ha}^{-1}, 16.6 \mathrm{~kg} \mathrm{ha}^{-1}$ and 266.33 $\mathrm{kg} \mathrm{ha}{ }^{-1}$, respectively. Organic carbon content was $0.32 \%$. The experiment was conducted on a three year old plantation of Leucaena leucocephala established in agroforestry models of agroforestry scheme planted with a spacing of 15 feet $x 5$ feet. The lopping experiment was conducted with Randomized Block Design with three replications. The treatments were $\mathrm{T}_{1}$ : lopping once in 2 months, $\mathrm{T}_{2}$ : lopping once in 4 months, $\mathrm{T}_{3}$ : lopping once in 6 months, $\mathrm{T}_{4}$ : lopping once in 8 months, $\mathrm{T}_{5}$ : lopping once in 10 months and $\mathrm{T}_{6}$ : lopping in 12 months. A total of 60 trees were selected to carry out this experiment. The treatments were randomized and imposed in three blocks each considered as a replication. Observations were made on the number of cutting branches, number of leaves, weight of branches and leaves, stem diameter at one meter height and cumulative green fodder yield. The leaves along with small and light branches, amenable for consumption by cattle were taken for yield calculation. 


\section{Results and Discussion}

In the present investigation, the mean values of growth parameters of subabul are presented in Table (1). During the period of study, number of branches were highest in the treatment where lopping was carried out once in 2 and 4 months and lowest in the treatments where lopping was carried out in trees with once in more than 6 months, while number of leaves was the highest in treatments with lopping once in 2 months but on par with lopping at 4 months and 6 months. The length of the branch cut was higher when the lopping interval is higher. The length of the branch cut was less in trees lopped once in 4 months. The better availability of growth resources and amenability of subabul for lopping leads to increase in number of branches and leaves.
The least reduction in leaf number and number of branches were found in treatments where lopping was carried out at longer intervals. This is in conformity with the findings of Onwudike (1995).

Lopping at increased time interval resulted in increased length of branch cut. When the trees are lopped at a base height of $1 \mathrm{~m}$ after 8 months, 10 months and 12 months resulted in increased length of branch cut. The time interval for lopping increases the branches tends to grow as there is more time available for extracting nutrients from soil (Sardar, 1990). There was no definite trend in the effect of lopping on the base stem diameter of gliricidia. This indicates that successive lopping may not have significance on the growth of trees. This is in agreement with the findings of Thenua et al., (1999).

Table.1 Effect of lopping interval on the growth parameters of Leucaena leucocephala

\begin{tabular}{|l|c|c|c|c|}
\hline Treatments & $\begin{array}{c}\text { No. of } \\
\text { Branches cut }\end{array}$ & $\begin{array}{c}\text { No. of leaves } \\
\text { per tree }\end{array}$ & $\begin{array}{c}\text { Length of } \\
\text { branch cut }(\mathbf{c m})\end{array}$ & $\begin{array}{c}\text { Base stem } \\
\text { diameter }(\mathbf{c m})\end{array}$ \\
\hline $\mathrm{T}_{1}$ : lopping once in 2 months & 10.90 & 427.6 & 59.06 & 5.97 \\
\hline $\mathrm{T}_{2}$ : lopping once in 4 months & 7.84 & 386.9 & 63.30 & 5.78 \\
\hline $\mathrm{T}_{3}$ : lopping once in 6 months & 5.91 & 348.3 & 93.08 & 5.78 \\
\hline $\mathrm{T}_{4}$ : lopping once in 8 months & 4.66 & 300.5 & 112.4 & 5.88 \\
\hline $\mathrm{T}_{5}$ : lopping once in 10 months & 4.54 & 291.4 & 121.3 & 5.97 \\
\hline $\mathrm{T}_{6}$ : lopping once in 12 months & 3.52 & 304.2 & 138.0 & 5.88 \\
\hline $\mathrm{CD}(\mathrm{p}=0.05)$ & 3.07 & 20.11 & 5.42 & $\mathrm{NS}$ \\
\hline
\end{tabular}

Table.2 Effect of lopping interval on the yield parameters and yield of Leucaena leucocephala

\begin{tabular}{|l|c|c|c|c|c|}
\hline Treatments & $\begin{array}{c}\text { Branch } \\
\text { (g DW) }\end{array}$ & $\begin{array}{c}\text { Leaf } \\
(\mathbf{g ~ D W})\end{array}$ & $\begin{array}{c}\text { Leaf: } \\
\text { Branch } \\
\text { Ratio }\end{array}$ & $\begin{array}{c}\text { Leaf } \\
\text { moisture } \\
(\mathbf{\%})\end{array}$ & $\begin{array}{c}\text { Yield } \\
(\mathbf{t} / \mathbf{h a} / \mathbf{y r})\end{array}$ \\
\hline $\mathrm{T}_{1}$ : lopping once in 2 months & 399.1 & 576.1 & 1.42 & 79.46 & 19.07 \\
\hline $\mathrm{T}_{2}$ : lopping once in 4 months & 412.9 & 461.3 & 1.09 & 78.66 & 17.72 \\
\hline $\mathrm{T}_{3}$ : lopping once in 6 months & 441.9 & 451.7 & 1.00 & 77.56 & 16.37 \\
\hline $\mathrm{T}_{4}$ : lopping once in 8 months & 466.5 & 389.8 & 0.81 & 73.68 & 15.06 \\
\hline $\mathrm{T}_{5}$ : lopping once in 10 months & 463.6 & 378.1 & 0.79 & 74.18 & 14.49 \\
\hline $\mathrm{T}_{6}$ : lopping once in 12 months & 484.0 & 394.8 & 0.79 & 73.18 & 15.80 \\
\hline $\mathrm{CD}(\mathrm{p}=0.05)$ & 16.31 & 11.92 & 0.62 & - & 1.35 \\
\hline
\end{tabular}


The main purpose of lopping is to procure fodder. Hence, the effect of various lopping intensities on fodder yield parameters and yield are presented here under (Table 2). Shorter lopping interval i.e. lopping once in 2 months and 4 months resulted in lesser branch weight (399.1g and $412.9 \mathrm{~g}$ ) even though the number of branches was found higher. However, lopping once in 2 months, 4 months and 6 months resulted higher leaf dry weight $(576.09 \mathrm{~g}, 461.3 \mathrm{~g}$ and $451.7 \mathrm{~g})$ which found proportional to the number of leaves per tree. The trees lopped with higher cutting interval resulted in more branch weight compared to leaf weight. The moisture content of the leaves also declined as the cutting interval increased. Increase in leaf number and weight resulted in increased leaf branch ratio, which is a considerable parameter to enhance vegetative biomass yield. In treatments with increased cutting interval the branches become little harder which is difficult for the animals to consume. The cumulative yield of subabul fodder was found higher in treatments with lopping once in 2 months and 4 months (19.07 $\mathrm{t}^{-1} \mathrm{ha}^{-1}$ year $^{-1}$ and $17.72 \mathrm{t}^{-1} \mathrm{ha}^{-}$ ${ }^{1}$ year $\left.^{-1}\right)$. It is in conformity with the findings of Kishankumar and Tewari (2000) and Vennila et al., (2016).

It can be concluded that, lopping once in 2 or 4 months resulted in increased yield of fodder and leaf shoot ratio. Further lopping of subabul once in 2 or 4 months was more efficient because the leaf and branches will be consumed evenly as the leaves and branches were younger and more succulent.

\section{References}

Kishan Kumar, V.S and Tewari, V.P. 2000, Effect of lopping on the top feed production and growth of Prosopis cineraria. Bioresource Tech., 7 4: 165168.

Nair, P.K.R. 1987, Agroforestry in the Indian Sub continent: Past, present and future. In: Singh, G.B. Steppler, H.A. (Eds.), Agroforestry: a decade of development. International Council for Research in Agroforestry (ICRAF), Nairobi, Kenya. 117-138.

Onwudike, O.C. (1995). Use of the legume tree crops Gliricidia sepium and Leucaena leucocephala as green feeds for growing rabbits. Animal Feed Sci. Tech., 51: 153-163.

Rawat, J.K. 1993, Economic considerations in tree lopping. Ind. For. 119:703-707.

Thenua, O. V. S., Verma, R. S. and Singh, T.P. 1999, Effect of subabul (Leucaena leucocephala) canopy on yield, quality and nitrogen uptake of clusterbean (Cyamopsis tetragonoloba) and sesame (Sesamum indicum) under agrosilviculture system. Indian J. Agron, 44(1): 68-72.

Vennila, C. Gunasekaran, S. and Sankaran, V. M. 2016, Effect of lopping interval on the growth and fodder yield of Gliricidia sepium. Agrl. Sci. Digest, 36(3): 228-230.

\section{How to cite this article:}

Vennila, C., M. Daisy and Bhuvaneswari, J. 2020. Effect of Lopping Interval on the Growth and Fodder Yield of Subabul (Leucaena leucocephala). Int.J.Curr.Microbiol.App.Sci. 9(09): 3552-3555. doi: https://doi.org/10.20546/ijcmas.2020.909.440 